\title{
Technological and economic study of ship recycling in Egypt
}

\author{
Yousri M. A. Welaya ${ }^{1}$, Maged M. Abdel Naby ${ }^{1}$ and Mina Y. $\operatorname{Tadros}^{1}$ \\ ${ }^{1}$ Department of Naval Architecture \& Marine Engineering, Alexandria University, Egypt
}

\begin{abstract}
The ship recycling industry is growing rapidly. It is estimated that the International Maritime Organization's (IMO) decision to phase-out single hull tankers by 2015 will result in hundreds of ships requiring disposal. At present, the ship recycling industry is predominantly based in South Asia. Due to the bad practice of current scrapping procedure, the paper will highlight the harm occurring to health, safety and environment. The efforts of the Marine Environment Protection Committee (MEPC) which led to the signing of the Hong Kong International Convention are also reviewed. The criteria and standards required to reduce the risk and damage to the environment are discussed and a proposed plan for the safe scrapping of ships is then presented. A technological and economic study for the ship recycling in Egypt is carried out as a case study. This includes the ship recycling facility size and layout. The equipment and staff required to operate the facility are also evaluated. A cost analysis is then carried out. This includes site development, human resources, machineries and equipment. A fuzzy logic approach is used to assess the benefits of the ship breaking yard. The use of the fuzzy logic approach is found suitable to make decisions for the ship breaking industry. Based on given constraints, the proposed model has proved capable of assessing the profit and the internal rate of return.
\end{abstract}

KEY WORDS: Ship recycling; Ship scrapping; Marine environment protection; Ship breaking yard; Fuzzy logic approach.

\section{NOMENCLARURE and ABBREVIATIONS}

$\begin{array}{llll}A & \text { Annual Amounts } & M E P C & \text { Marine Environment Protection Committee } \\ i & \text { Internal rate of return per year } & N & \text { Number of years } \\ I C S & \text { Industry Code of Practice } & N P V & \text { Net Present Value } \\ I L O & \text { International Labor Organization } & O S H & \text { Occupational Safety and Health } \\ I M O & \text { International Maritime Organization } & P & \text { Present worth } \\ I R R & \text { Internal Rate of Return } & S P W & \text { Single Present Worth }\end{array}$

\section{INTRODUCTION}

Due to the fast growth in ship recycling industry worldwide, especially in Asian countries such as India, Bangladesh, China and Pakistan, it has become a major source of income for those countries. However, there is a growing concern in the international maritime community over the conditions in which ships are scraped at present. The need to develop stringent laws to guarantee the safety of personnel working in this industry and the surrounding environment is extremely important.

There are great prospects for this industry in Egypt due to the excellent location of Egypt in the international trade route.

Corresponding author: Yousri M. A. Welaya

e-mail:y_welaya@hotmail.com 
This is enhanced by the fact that many ships are about to phase-out of service in the nearby European continent.

Therefore, this paper aims at presenting an economic and technological study for ship recycling in Egypt, taking into consideration the safety of workers and surrounding environment. A historical background and the developed international regulations concerning ship recycling are presented. This is followed by a case study to operate such a facility in Egypt and a cost analysis is carried out using a fuzzy logic approach.

\section{HISTORICAL BACKGROUND}

Ship recycling contributes to sustainable development and it is the most environmentally friendly way of disposing of ships with virtually every part of the hull and machinery capable of being re-used, as shown in Fig. 1 (Shama, 2004). In the 1970's ship breaking was done in the docks of Europe. It was a highly mechanized industrial operation. But as European countries grew more conscious of environmental standards, and health and safety measures, cost of scrapping began to escalate.

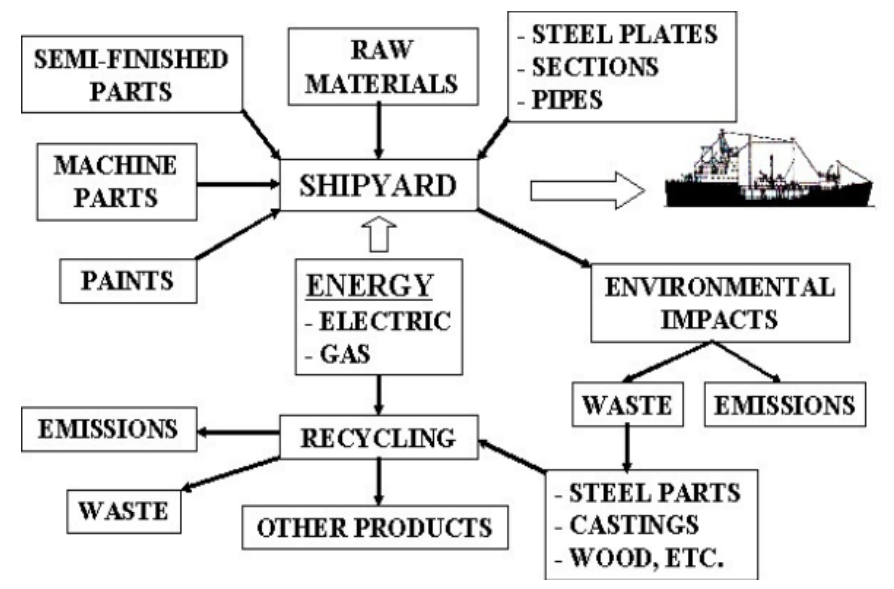

Fig. 1 Ship life cycle (Shama, 2004).

About $90 \%$ of the ship breaking industry predictably moved to Asian countries, to India, Bangladesh, China, Pakistan and Turkey, poorer nations with lax environmental and safety standards where you can see women carrying asbestos waste on their heads and dumping it in the sea due to lower labor costs and less stringent environmental regulations dealing with the disposal of lead paint and other toxic substances. You can also see workers with bare hands using acetylene torch cutters to dismantle huge sea carriers into small pieces (International Marine Consultancy, 2007; Andersen, 2001).

\section{INTERNATIONAL REGULATIONS CONTROLLING SHIP RECYCLING}

Many international attempts such as those made by the Basel Convention (The Basel Convention, 1989), the International Labor Organization (Marine Environment Protection Committee (MEPC), 2003), the flag state obligations (SCIES and SEPA, 2008), Port State control rights (Germanischer Llyod, 2010) were crowned by the effort of the MEPC from 1998 (Mikelis, 2006) which led to the signing of the Hong Kong International Convention in 2009. The International Maritime Organization (IMO) is responsible for the coordination between all such bodies to attain the safety aspects in ship scrapping industry (Mikelis, 2006).

The most important document used in this respect is the "Green Passport" which contains the details of the ship and a list of the hazardous materials and their locations and the approximate quantity/volume of each identified material on board the ship. This document will guarantee more protection for the environment during scrapping of ships at the end of their life (IMO, 2003).

\section{SAFE SHIP BREAKING PLANS AND OPERATIONS}

The breaking of a ship can be divided into three core phases: preparation, deconstruction and material stream management. 
These may be further subdivided to identify the constituent work processes (ILO, 2004). Each of these phases and the constituent work processes are briefly discussed below:

\section{Preparation phase}

Within the preparation phase - before a vessel arrives and up to the time when deconstruction operations actually begin the following elements should be addressed:

(1) Compliance with International, national and industry regulations and guidelines: these include IMO guidelines on ship recycling, the technical guidelines for the environmentally sound management of the full and partial dismantling of ships of the Basel Convention, ICS Industry Code of Practice on Ship Recycling, national guidelines on OSH, or any equivalent regulatory or code of practice requirements.

(2) Verification of the stated facts in the "green passport" or other inventory of materials document or arrangements to survey the ship if no inventory is provided.

(3) Details covering hazardous wastes should be located and, if possible, clearly and distinctly marked on the ship and identified on the safe shipbreaking schedules and any working drawings, plans, instructions to subcontractors etc.

(4) Plans to arrange for and carry out any residual gas freeing, cleaning of tanks/compartments and removal of any cargo residues (chemical or otherwise posing a hazard) should be prepared.

(5) Shutting down and decommissioning of hydraulic systems, boilers, fire protection systems, fuel oil and electrical systems such as generators and incinerators, freshwater systems, feed tanks and associated fittings.

\section{Deconstruction phase}

All main deconstruction and sub-processes should be identified in the safe ship breaking schedules. These will include:

(1) Determination and implementation of the applicable preventive and protective measures based on safe work principles and any completed risk assessments.

(2) Development of a work plan and, on a daily basis, ensuring that it does not place workers in dangerous positions, e.g. the work plan does not allow one group of workers to work directly above others working at a lower level.

(3) Allocation of human resources throughout the site.

(4) Determining the positions of tools and equipment to be used.

\section{Material stream management phase}

This final core phase applies to the management of materials that arise from the primary activity of ship deconstruction. Such materials may be termed waste or scrap or, in the case they have a secondary use, materials to be recovered, reused or recycled. The following are indicative activities normally carried out in this phase of the safe ship breaking plan:

(1) Secondary deconstruction: the breaking down of large items once removed from the main ship structure, i.e. the cutting down of large sections for further processing and disposal.

(2) Sorting: identifying similar metals or components into groups of the same, i.e. valves, pipes, dissimilar metals (brass from steel), etc.

(3) Separation: the disengaging of one element from another, e.g. copper wire from cables, asbestos from pipes, paint removal, etc.

(4) Reception facilities: to include suitable provisions to receive liquids/solids, hazardous substances and other inventory materials.

(5) Disposal: the appropriate means and arrangements to safely dispose of materials that cannot be recovered, recycled or passed on to another user for reuse, i.e. incineration and landfill.

(6) Recycling: materials and machinery that may or may not require additional processing before it is sold or put to another purpose including reuse. 
The breaking area should be zoned to ensure each type of downstream material is positioned and handled so as not to pose a hazard or threat to the safety and health of workers on the site, adjacent work areas or residents of a danger zone(s) outside the facility boundaries. Fig. 2 shows how a site may be subdivided to prevent and reduce the risk of accidents from materials being handled, processed and stored.

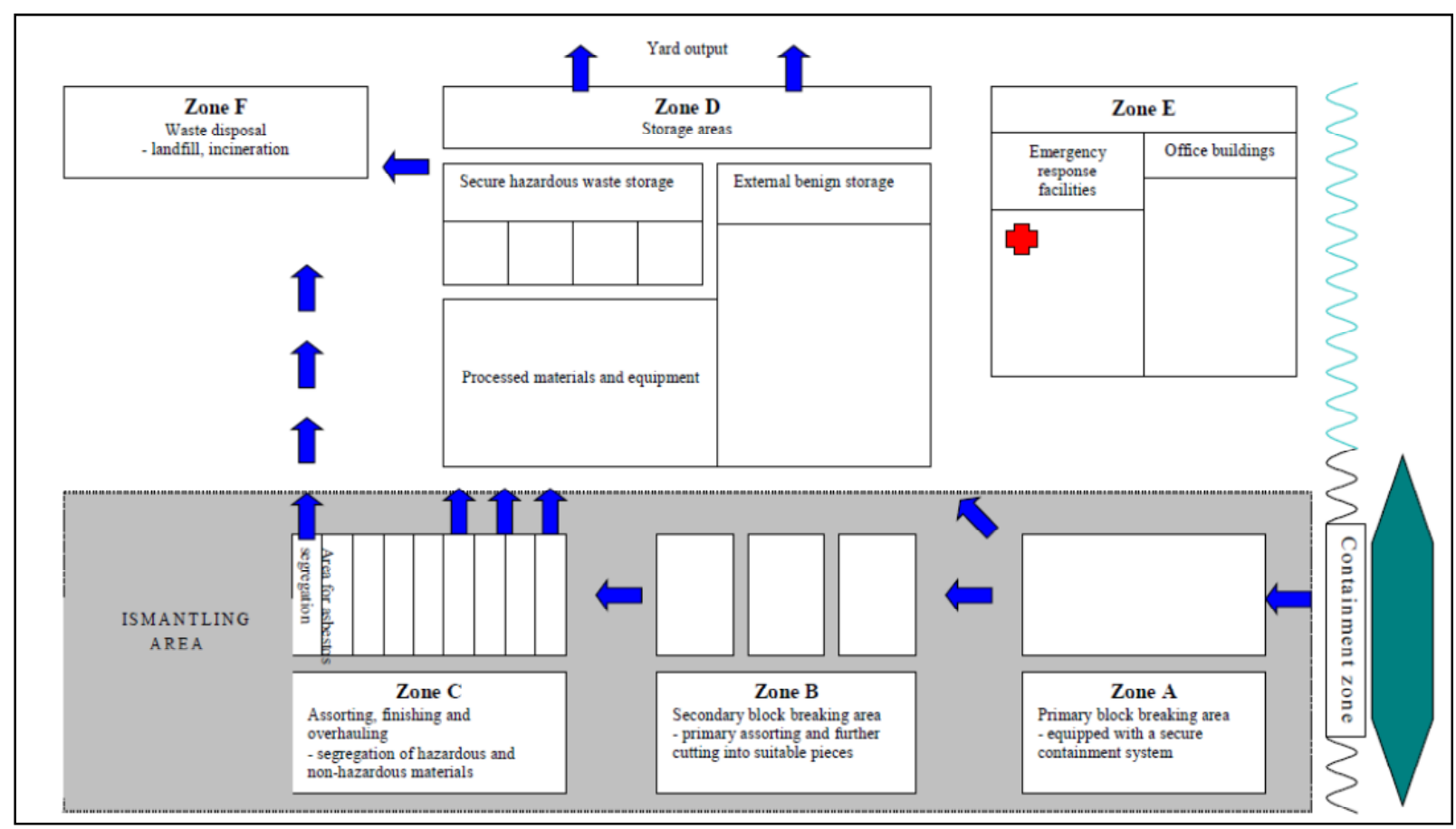

Fig. 2 The zoning of the ship breaking area (The Basel Convention, 1989).

\section{AN OVERVIEW OF THE TECHNICAL REQUIREMENTS TO OPERATE A SHIP RECYCLING FACILITY IN EGYPT}

The Size of ship breaking yards can be classified into small $\left(<50,000 \mathrm{~m}^{2}\right)$, medium $\left(50,000-500,000 \mathrm{~m}^{2}\right)$, and large $\left(>500,000 \mathrm{~m}^{2}\right)$. There are many factors that affect the size of the ship breaking yard. After studying the market in Egypt, a medium ship breaking yard is chosen, which is suitable to dismantle a ship of a maximum length of $230 \mathrm{~m}$. For an efficient recycling operation, the yard must possess at least one wet berth and one dry dock for the final dismantling of the ship. Fig. 3 represents a general layout for the proposed ship breaking yard (Tadros, 2012).

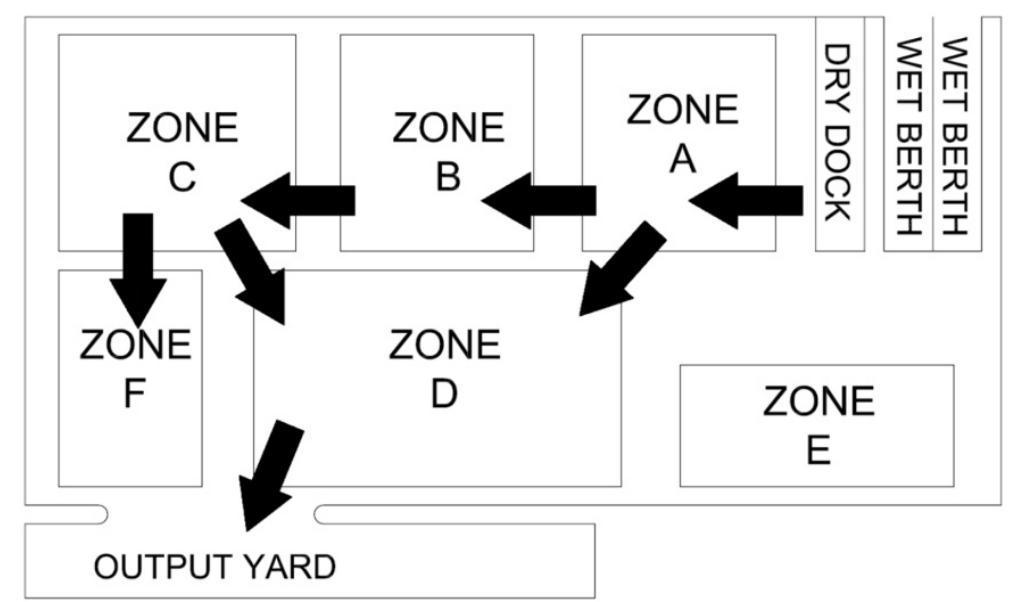

Fig. 3 General layout for the proposed ship breaking yard in Egypt (Tadros, 2012). 
The type and number of staff required to dismantle a ship with light weight of 2,500 to 10,000 tonne is assumed to be 39 . This does not include shift staff and subcontractors. The actual number of staff will depend on the size of the facility, the number of ships being dismantled and the time allocated for the dismantling process. The management staff would not necessarily be dedicated to a single ship recycling project. The equipment required to dismantle a ship would depend on the operational requirements and the amount of investment a site owner is willing to make (Department for Environment, Food and Rural Affairs (Defra), 2007).

\section{ECONOMIC FEASIBILITY STUDY FOR A SHIPBREAKING YARD}

To make an economic feasibility study for a ship breaking yard, we have to make out a range of profit and internal rate of return (IRR) of the yard along a period of 20 years according to different ranges of input data for each type of cost as discussed below. These economic indices cannot be calculated directly due to the lack and inaccuracy of data, so the use of the Fuzzy Logic approach is proposed.

\section{Determining profit value with fuzzy logic}

There are several stages to go through to determine the profit value for a ship breaking yard (Soetanto, 2000):

(1) The determination on the most dominant factors which influence the profit.

(2) Data collection through interviews and questionnaires.

(3) The design of Fuzzy Inference System.

(4) Fuzzy Inputs.

(5) Fuzzy Operator Application.

(6) If-Then Rules Application.

(7) Defuzzification.

(8) Simulation.

\section{Determining the dominant factors}

The dominant factors which influence the price directly as discussed above is divided into two categories, input and output: The output cost is divided into:

(1) Cost of infrastructure.

(2) Cost of equipment.

(3) Cost of purchase of ships.

(4) Cost of labor.

(5) Cost of transportation.

The revenue or input is concentrated mainly in selling the scrapped steel from a ship's hull.

\section{Data collection}

The first thing to do is setting up the membership function. To support this, data collection is conducted through interviews with some shipyard managers, academic staff and by searching the web.

Table 1 represents the cost of purchasing ships as obtained from available published data together with the resulting effect on the profit. Infrastructure and equipment cost, labor and transportation cost, and material value according to the prices and conditions in Egypt are shown in Tables 2, 3 and 4 respectively, together with the effect on profit. 
Table 1 Classification of purchase cost of ships.

\begin{tabular}{|c|c|}
\hline Cost of purchase of ships & Effect on the profit \\
\hline$<\$ 4,000,000$ & Cheap \\
\hline$\$ 4,000,000-\$ 36,000,000$ & Average \\
\hline$>\$ 36,000,000$ & Expensive \\
\hline
\end{tabular}

Table 2 Classification of infrastructure and equipment cost.

\begin{tabular}{|c|c|}
\hline Cost of infrastructure and equipment & Effect on the profit \\
\hline$<\$ 100,000,000$ & Cheap \\
\hline$\$ 100,000,000-\$ 190,000,000$ & Average \\
\hline$>\$ 190,000,000$ & Expensive \\
\hline
\end{tabular}

Table 3 Classification of labor and transportation cost.

\begin{tabular}{|c|c|}
\hline Cost of labor and transportation & Effect on the profit \\
\hline$<\$ 650,000$ & Cheap \\
\hline$\$ 650,000-\$ 1,850,000$ & Average \\
\hline$>\$ 1,850,000$ & Expensive \\
\hline
\end{tabular}

Table 4 Classification of material value.

\begin{tabular}{|c|c|}
\hline Value of material & Effect on the profit \\
\hline$>\$ 72,000,000$ & More benefit \\
\hline$\$ 72,000,000-\$ 8,000,000$ & Average benefit \\
\hline$<\$ 8,000,000$ & Less benefit \\
\hline
\end{tabular}

\section{Fuzzy inference system design}

Fuzzy inference is the actual process of mapping from a given input to an output using fuzzy logic. This model can be implemented by using MATLAB. MATLAB is a technical computing environment for high-performance numerical computation and visualization. MATLAB integrates numerical analysis, matrix computation, signal processing, and graphics in an easyto-use environment where problems and solutions are expressed just as they are written mathematically without traditional programming. In this study, the MATLAB ver. 7.6.0 with Fuzzy Logic Toolbox is used.

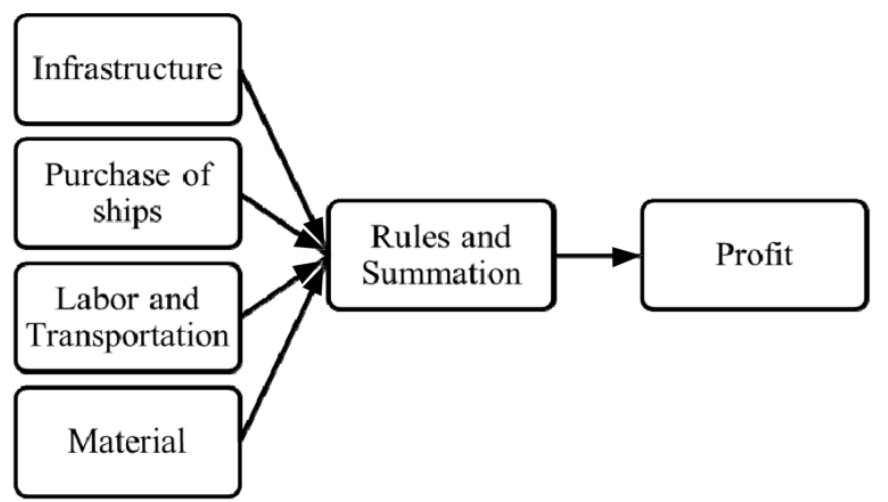

Fig. 4 Fuzzy inference system (Soetanto, 2000). 


\section{Fuzzy input}

To give picture on the membership function towards the different costs, the triangular membership function is used. The triangular curve depends on three parameters as given by:

$$
f(x ; a, b, c)=\left\{\begin{array}{cl}
0, & x \leq a \\
\frac{x-a}{b-a}, & a \leq x \leq b \\
\frac{c-x}{c-b}, & b \leq x \leq c \\
0, & c \leq x
\end{array}\right.
$$

This triangular function is chosen as it has the capability of depicting the opinion of the managers accurately and the results are nearer to the truth than any other functions. All costs are presented in million $\$ / y e a r$.

The following assumptions are made:

(1) There are two options for the ratio between material value and purchase cost:

a) The value of material is twice the purchase cost of ships.

b) The value of material is triple the purchase cost of ships.

Both options shall be considered as in Table 4.

(2) The infrastructure and equipment cost is taken as indicated in Table 1, where these costs will be borrowed from the banks due to its high cost - to be paid back in a period of 20 years which is approximately half the life time of a shipbreaking yard with $7 \%$ interest rate.

(3) The labor and transportation cost is taken as in Table 3.

(4) Take the defuzzification strategy as "the center of area defuzzification" or "centroid".

\section{The first case: The value of material is twice the purchase cost}

The following equation is an example of the sum of costs of infrastructure and equipment, and labor and transportation:

$$
f(x ;-17,-13.5,-10)=\left\{\begin{array}{cl}
0 & , x \leq-17 \\
\frac{x-(-17)}{-13.5-(-17)},-17 \leq x \leq-13.5 \\
\frac{-10-x}{-10-(-13.5)},-13.5 \leq x \leq-10 \\
0 \quad,-10 \leq x
\end{array}\right.
$$

The triangular function for the sum of these inputs is shown in Fig. 5. This triangular membership function (MF) is a curve that defines how each point in the input space is mapped to a membership value (or degree of membership) between 0 and 1 . A triangular function is also used to portray the membership function for the difference between material value and purchase cost in million \$/year as shown in Fig. 6.

\section{The second case: The value of material is triple the purchase cost}

The infrastructure and equipment, and labor and transportation costs are the same as in the first case. The change is only in the ratio between material value and purchase cost of ships as in Fig. 7. 


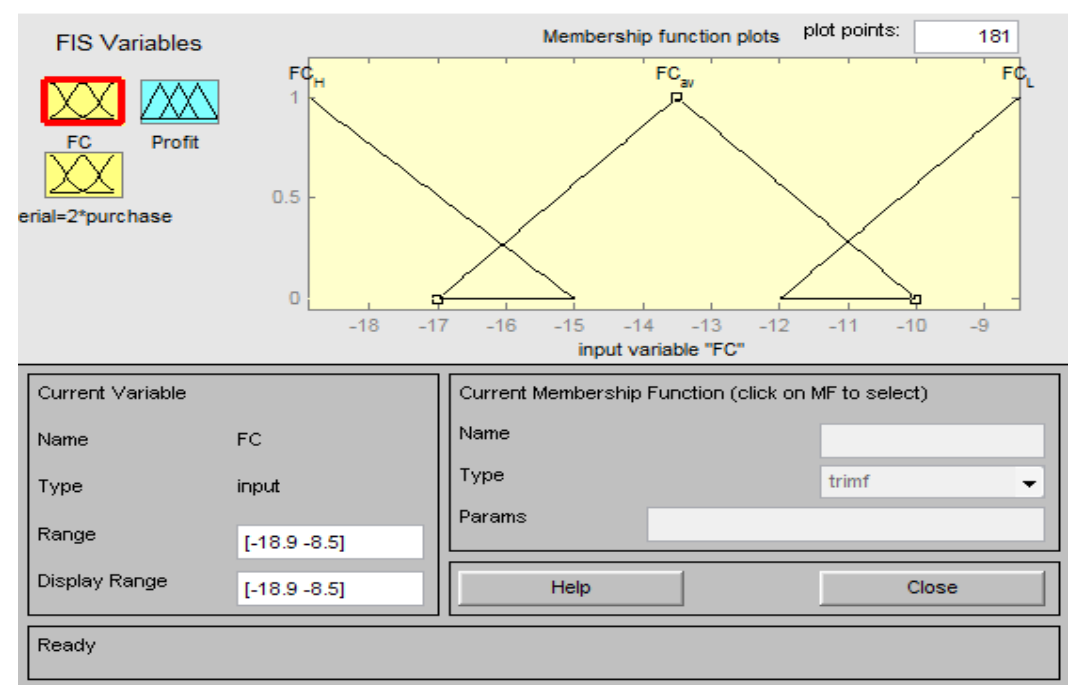

Fig. 5 Matlab display infrastructure, equipment, labor and transportation cost membership function.

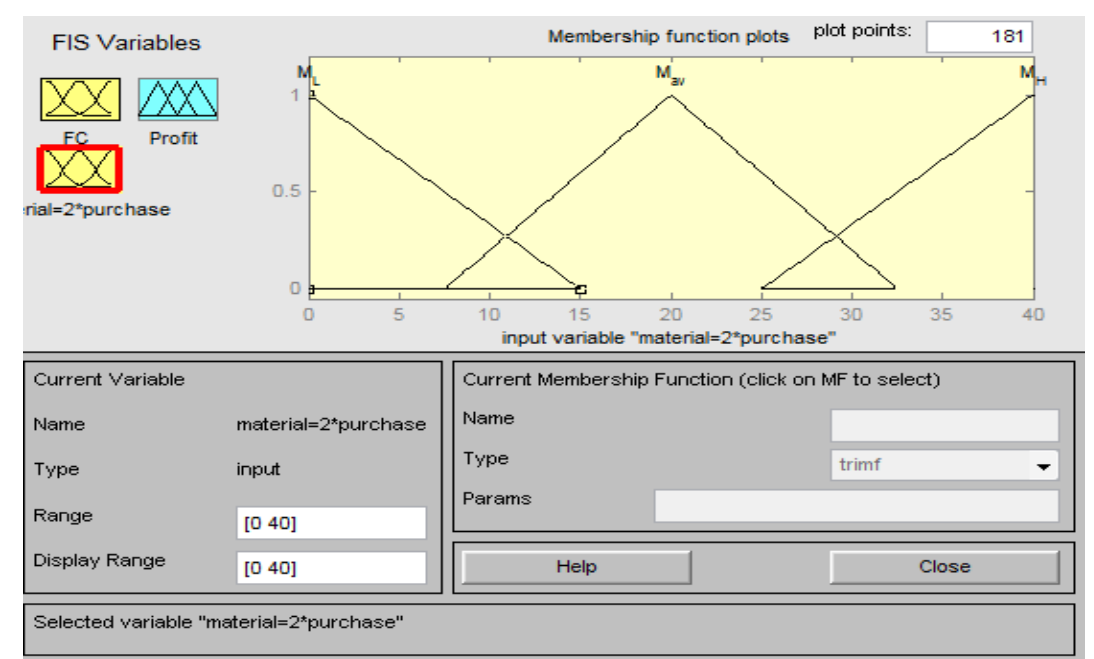

Fig. 6 Matlab display ratio between material value and purchase cost of ships membership function.

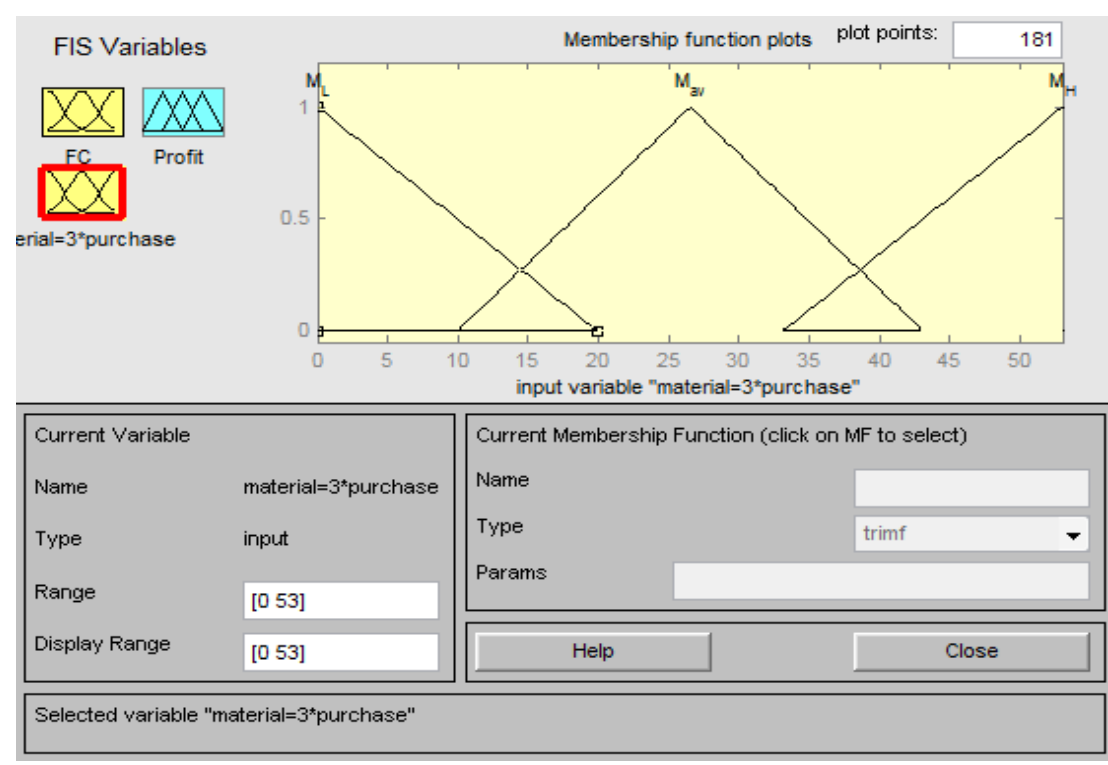

Fig. 7 Matlab display ratio between material value and purchase cost of ships membership function. 


\section{The surface viewer}

Upon opening the Surface Viewer, we are presented with a two dimensional curve that represents the mapping from service quality to tip amount. Since this is a one-input one-output case, we can see the entire mapping in one plot. Two input oneoutput systems also work well, as they generate three-dimensional plots that MATLAB can adeptly manage. But when we move beyond three dimensions overall, we start to encounter trouble displaying the results. In this study, we can present the relations with two inputs at the $\mathrm{x}$ axis which represents the sum of infrastructure, equipment, labor and transportation costs and the $\mathrm{y}$ axis which represents the difference between material value and purchase cost, and one output at $\mathrm{z}$ axis which represent the profit.

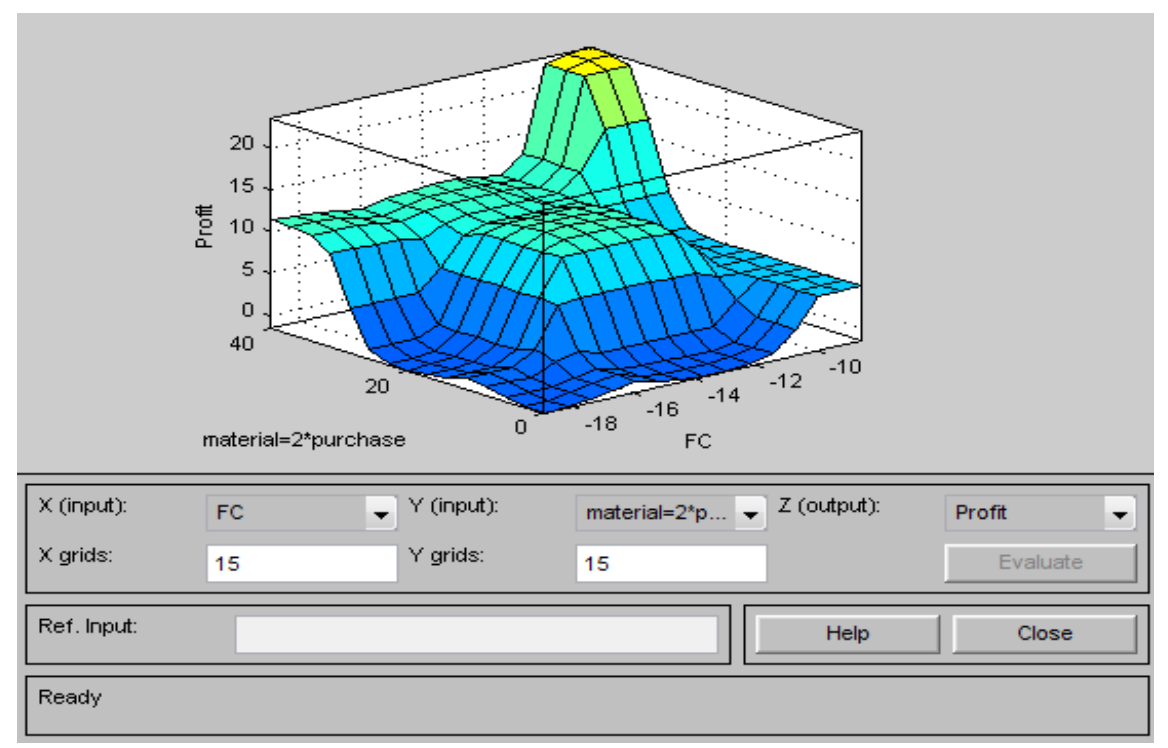

Fig. 8 Matlab display ratio between material value and purchase cost - Fixed cost - Profit surface in the first case.

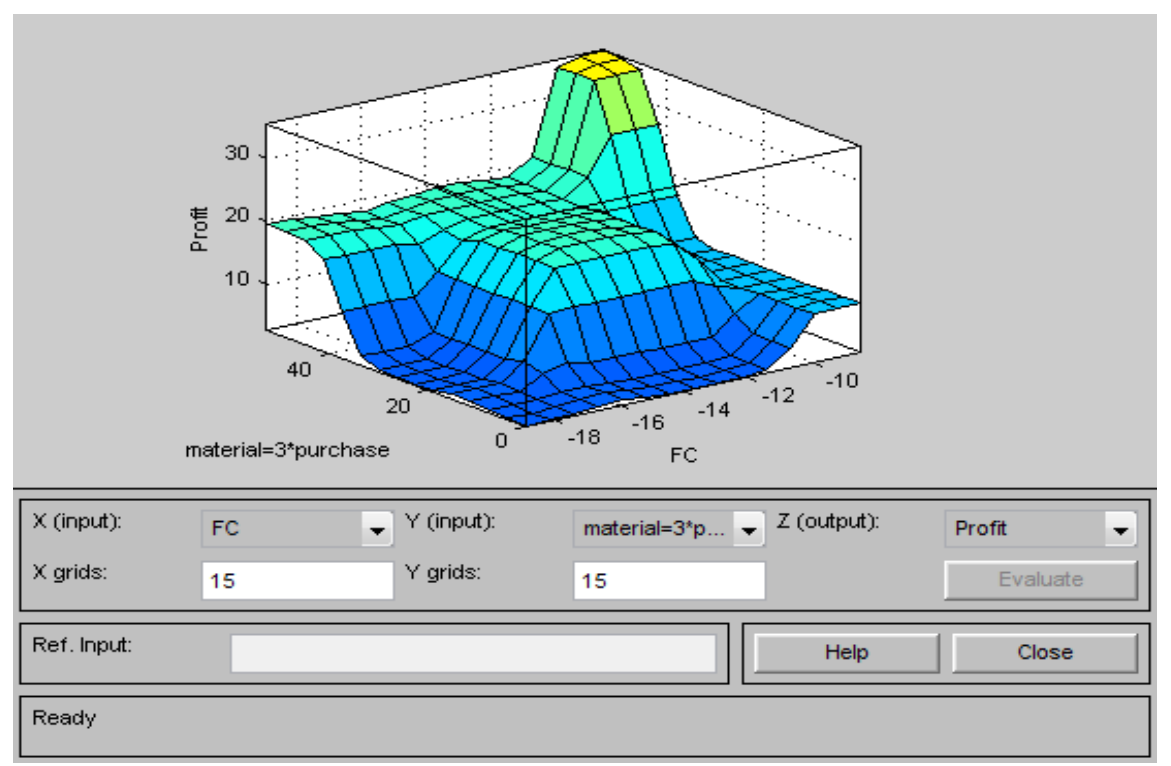

Fig. 9 Matlab display ratio between material value and purchase cost - Fixed cost - Profit surface in the second case.

By knowing the exact value of infrastructure and equipment cost, labor and transportation cost, purchase cost and material value, we can determine the profit. From Fig. 8 and 9, the profit takes the maximum value when the difference between purchase cost and material value is very high despite a change of the fixed cost. The profit begins to increase when the ratio between purchase cost and material value decreases. 


\section{Calculation of the internal rate of return}

To calculate the IRR, all the variable costs have to be presented along a period of 20 years in a cash flow diagram to determine the profit and then calculate the IRR by applying the following equation:

$$
N P V=A(S P W-i-N)-P
$$

Where,

$$
\begin{array}{ll}
N P V & =\text { Net present value }=0 \\
A & =\text { Annual Amounts } \\
i & =\text { Internal rate of return } \\
N & =\text { Number of years } \\
S P W & =\text { Single present worth } \\
P & =\text { Present worth }
\end{array}
$$

The following cash flow diagram in Fig. 10 shows the relation between costs over 20 years. Fig. 11 shows the relation between IRR on the Y-axis and infrastructure, labor and transportation in the $\mathrm{X}$-axis according to the variation of material value (revenue) from $\$ 40,000,000$ to $\$ 80,000,000$ in case where the purchase cost is equal to $1 / 2$ the material value. The

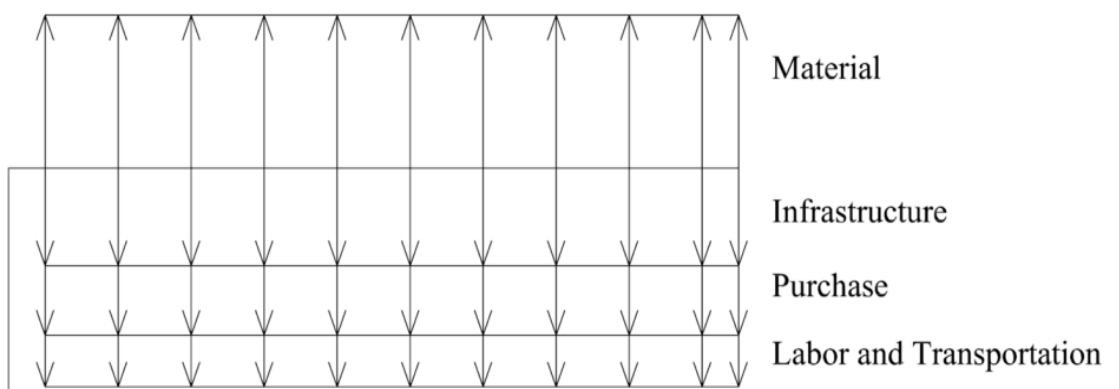

Infrastructure

Fig. 10 Cash flow diagram for shipbreaking yard costs.

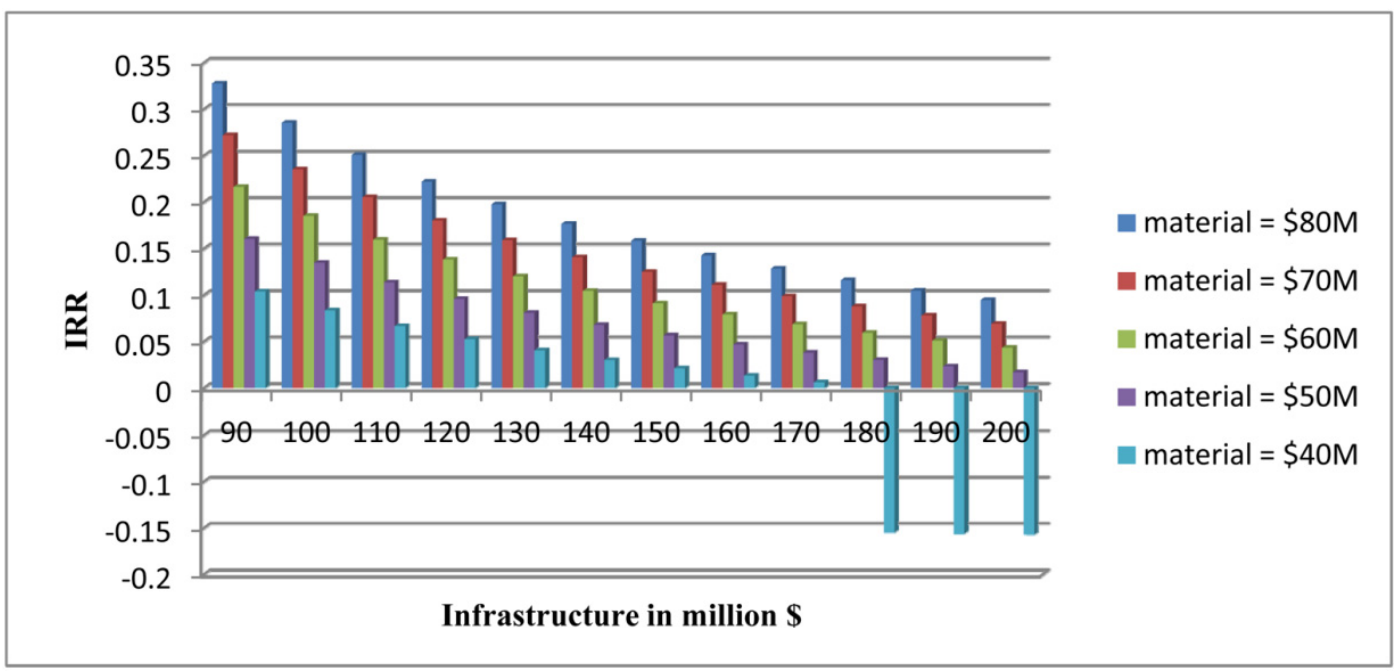

Fig. 11 Relation between IRR and infrastructure with variation of material value from (\$80 M - \$40 M). 
average IRR acceptable in this industry is from 0.05 to 0.25 to protect itself from any drops in the stock market along the years and achieve the optimum profit.

To be on the safe side and achieve the optimum profit, the revenue must not be less than the $\$ 50,000,000$ and this means that the shipbreaking yard must scrap more than 14 ships per year with an average length of 170-200 $\mathrm{m}$ in which the value of each scrapped ship can be from $\$ 3,000,000$ to $\$ 6,000,000$ according to its length. If the revenue is less than $\$ 50,000,000$, this industry becomes in a critical situation where the IRR will approach zero then go towards the loss case.

When the purchase cost is equal to $1 / 3$ the material value, the IRR will be better than the previous case. This relation will be shown in Fig. 12.

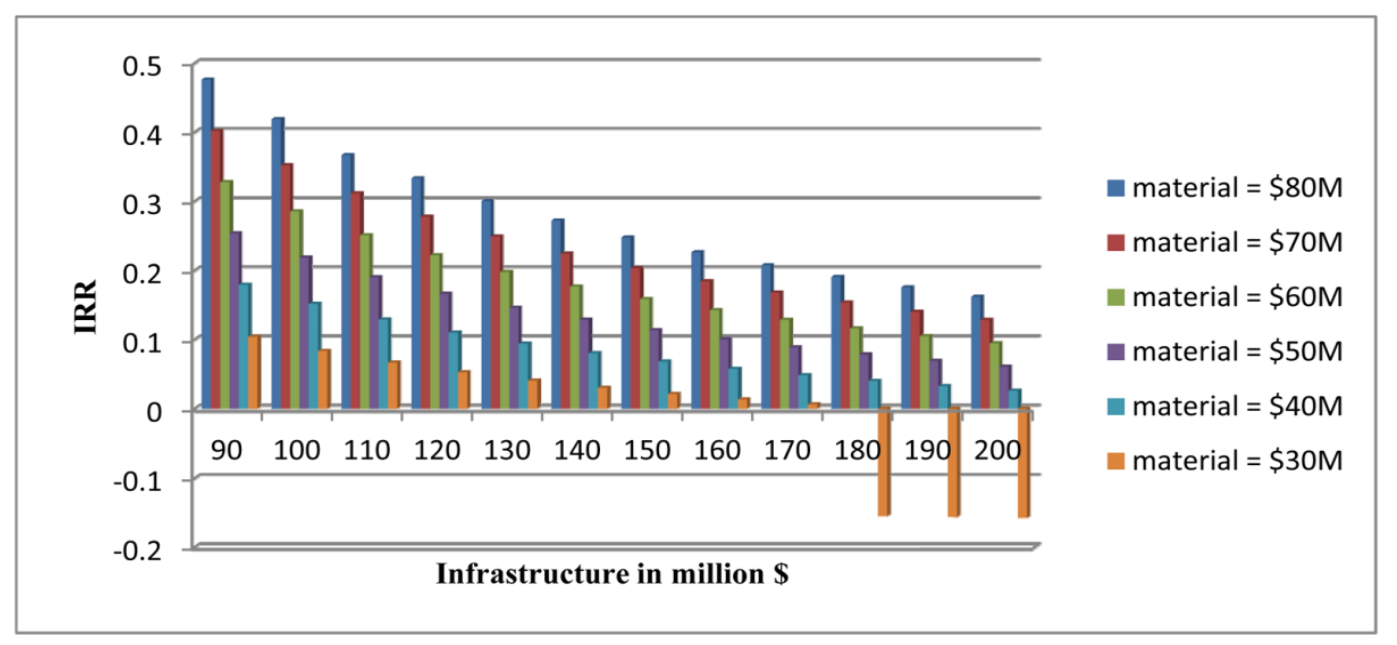

Fig. 12 Relation between IRR and infrastructure with variation of material value from $(\$ 80 \mathrm{M}-\$ 30 \mathrm{M})$.

From Fig. 11, the safe side will be at $\$ 40,000,000$ revenue and less than the previous case with $\$ 10,000,000$ in which the ship breaking yard must scrap from 10 to 12 ships per year. If the number of ships is less than that, the project becomes in a critical case and the IRR moves toward zero and then will be negative.

\section{CONCLUSIONS}

(1) The bad practice of current scrapping procedure causes serious harm to health, safety and environment.

(2) Ship recycling industry must conform to all national and international regulations and conventions. These include IMO, ILO, Basel Convention, MEPC, etc. If the safety standards and criteria are strictly followed, ship recycling will become a clean and safe industry.

(3) The fuzzy logic approach used to assess the benefits of the ship breaking industry is found suitable to make decisions. Based on given constraints, the proposed model has proved capable of assessing the profit and the internal rate of return.

(4) The results of the study carried out show that the location of the ship breaking yard does not affect the cost of labor and transportation. It, however, affects the infrastructure cost.

(5) The final decision whether to start a ship recycling industry or not, depends on some factors such as the price of scrapped items and the expected number of ships to be scrapped.

\section{REFERENCES}

Andersen, A.B., 2001. Worker safety in the ship-breaking industries. International Labour Office, Geneva.

Department for Environment, Food and Rural Affairs DEFRA, 2007. Overview of ship recycling in the UK, Guidance, UK. Germanischer Llyod, 2010. Thomas Schulte Contracts GL for Certified Ship Recycling. [online] Available at: <http://www. gl-group.com/cn/snb/6996.php> [Accessed January 2011]. 
ILO, 2004. Safety and health in shipbreaking: Guidelines for Asian countries and Turkey (ISBN 92-2-115289-8). Geneva. IMO, 2003. IMO Guidelines on Ship Recycling, Resolution A.962(23), Adopted on 5 December (Agenda item 19).

International Marine Consultancy, 2007. Where Ships Go to Die. [online] Available at: <http://www.imcbrokers.com/blog/ overview/p/detail/where-ships-go-to-die> [Accessed January 2011].

Marine Environment Protection Committee (MEPC), 2003. Recycling of ships. 49th session, Agenda item 3. 28 March 2003.

Mikelis, N.E., 2006. Developments and issues on recycling of ships. East Asian Seas Congress. Haikou City, Hainan Province, PR China 12-16 December 2006.

SCIES and SEPA, 2008. Regional review on the status of implementation of marine/coastal-related Multilateral environmental agreements "meas" in the East Asian seas region. [online] Available at: $<\mathrm{http}$ //www.cobsea.org/documents/ Meeting_Documents/MEAs\%20Forum/Final\%20MEA\%20Review\%202008.pdf> [Accessed January 2011].

Shama, M.A., 2004. Life cycle assessment of ships. Alexandria Engineering Journal, 43(5), pp.631-637.

Soetanto, D.P., 2000. Implementing fuzzy logic in determining selling price. Journal TeknikIndustri, 2(1), pp.42-52.

Tadros, M.Y., 2012. Technological and economic feasibility study of ship recycling in Egypt. M.Sc. Thesis, Alexandria University.

The Basel Convention on the Control of Transboundary Movements of Hazardous Wastes and Their Disposal, Basel, 1989. Audiovisual Library of International Law. [online] Available at: $<$ http://untreaty.un.org/cod/avl/ha/bcctmhwd/bcctm hwd.html> [Accessed January 2011]. 